\title{
The Merits of Specialized Microfinance Instruments and Their Feasibility in Alleviating Poverty in Albany-Dougherty County, Georgia
}

\author{
Amaechi N. Nwaokoro ${ }^{1}$, Abiodun Ojemakinde ${ }^{1}$ \& Lee Washington ${ }^{1}$ \\ ${ }^{1}$ College of Business, Albany State University, 504 College Drive, Albany, Georgia 31705, USA \\ Correspondence: Amaechi N. Nwaokoro, Ph.D, College of Business, Albany State University, 504 College Drive, Albany, \\ Georgia 31705, USA. Tel: 229-430-4723.
}

Received: August 16, 2017

Accepted: September 7, 2017

Online Published: October 17, 2017

doi:10.5430/ijfr.v8n4p134

URL: https://doi.org/10.5430/ijfr.v8n4p134

\begin{abstract}
Albany-Dougherty County, Georgia has poverty-related indexes that include unemployment and economic disparity. The high unemployment and deteriorating economic climate can be traced to an exodus of major manufacturing employers. Public health issues and educational services continue to decline. These proxies of misery must be addressed by a contemporary mix of market related factors of financing and entrepreneurial enthusiasm. This research addresses the ever increasing poverty and related challenges on the road to prosperity. Secondly, this exploratory study highlights the relevance of a mix of micro-financing instruments that could assist the community to engage market-based economic activities that could enhance economic profiles. Based on the data collected with a survey instrument, the study highlights an apparent reluctance of concessionary financial institutions to lend.
\end{abstract}

Keywords: microfinance, microfinance-instruments, alleviating poverty, concessionary lending

\section{Introduction}

Economic recovery in Albany-Dougherty County is disappointedly slow. Accessibility to and understanding of market related institutions are very important for alleviating long- term poverty. A prolonged decrease in economic prosperity impacts the quality of life and robs the community of its educationally gifted and talented citizens. Enhanced participation of citizens, in economic markets, with assistance from market institutions, such as microfinancing, can increase earned income of local citizens and reduce poverty. Once provided resources and entrepreneurial freedom, the business sector is capable of producing products and services. A continuous flow of fund is required to support targeted business ventures. The establishment of micro financial institutions can provide the economy with opportunities to access different concessionary financial instruments.

Albany-Dougherty County is rural and located in a remote section of Southwest Georgia. The county has a population of 96,065, (Note 1) and the county's population distribution of Blacks, White, and Hispanics is $60.1 \%, 37.34 \%$, and $1.3 \%$ respectively (Note 2). This population is declining as upwardly mobile middle class residents migrate to distant economically prosperous communities. The departure of these residents has the impact of reducing the tax base in Albany-Dougherty County. Also, the closure of some large businesses has led to high dimensional unemployment. This remote county is characterized by high unemployment and economic disparity, and indexes of poverty that have led to the City of Albany's ranking as the fourth poorest community in the nation (Note 3).

Albany-Dougherty community would benefit from efforts that are inclusive of all its citizens to engage in economic activities. Non-market, exogenous factors, such as discriminations and racism tend to limit access to capital and to other economic opportunities for any community. An economy is expected to expand to provide more opportunities, allowing residents to engage in various prosperous economic activities. A financially deprived community is least prepared to participate in the economic market. This creates a vicious circle of poverty and even greater occurrences of crime. The community seeks opportunities to pursue its dreams by providing economic opportunities to all citizens to be productive members of society.

Traditional lenders are increasingly reluctant to provide loans to borrowers with little or no acceptable collateral because traditional lending institutions lack incentives to pioneer programs that target borrowers who are less than creditworthy. An impoverished community will encounter loan approval resistance from traditional lenders. On the other hand, microfinance sectors would provide financial inclusion to underserved communities, which may not be the 
goal of the conventional banks. Specifically, microfinance institutions lend to high-risk borrowers which traditional banks deny. The competitiveness of micro finance sectors can also precipitate a decline in the interest rates charged by "Payday" lenders and "Check Cashers" sectors. Servon \& Bates (1998) explain that the poor who lack knowledge of the market can be assisted with some programs that can emancipate them from poverty. Exposing these market norms to the poor citizens can elevate their involvement in the markets and encourage their interest in the markets with the assistance of specialized loans or some kinds of specialized financial instruments.

Microfinance originated as a mechanism for alleviating poverty by extending microcredit funds to a group of entrepreneurs who engage in small scale businesses but need small financial capital to start and operate the businesses. The introduction of the idea of microfinance can be traced to the Germany Bank Movement and Chicago's Shore Bank. Dr. Muhammad Yuns practically implemented the microfinance idea with an establishment of Grameen Foundation of Bangladesh that set the pace for poverty alleviation by transferring enterprise funds to the community. The foundation utilized the "Solidarity Lending Method" that recognizes group financial strength and amalgamates funds that are transferred to some particular groups of the community. Transferring funds to a community aims to minimize the probability associated with default risk. Also, this approach of transferring funds is reported to reduce the cost of acquiring funds (Note 4).

With the recent industry innovation of commercializing some part of the industry, microfinance establishments are classified in three groups-Formal Financial Sector Institutions, Semi-Formal Financial Sector Institutions, and Informal Sector Financial Institutions. The Formal Financial Sector includes Development and Microfinance Banks, Non-Bank Financial Institutions, Contractual Savings Institutions that relate to pension funds and insurance establishments, and Commercial Banks. In the semi-formal sector, there are multi-purpose cooperatives, quasi-cooperative banks, employee savings funds, village banks, development projects, and credit unions that are organized and owned by the members.

For the Informal Financial Sector that has the most establishments, there are private lender establishments, i.e., money lenders, traders and store keepers, and employee associations called "Susu" in Nigeria. The Formal and Semi-Formal institutions are regulated, but the Informal Institutions are not. The Welfarists - the advocates for the informal organizational establishments - see the informal financial set-ups as being more appropriate than do other establishments for addressing the needs of the community. They see the set-ups as more flexible and having closer relationships to the customers than do formal institutions and using different and complete approaches to lending and to addressing the needs of a community. On the other hand the Institutionalists-advocates for formal establishments - prefer the formalization of microfinance establishments. Formalization would enhance economies of scale from the specialized financial products and service outreach.

With diverse functions and customer focus, formal financial institutions could be the appropriate avenues to providing the poor with the applicable specialized final products and services for meaningful long-term poverty alleviation, and this favors the formalized microfinance sector to encourage specialized and concessionary lending for alleviating poverty. In South America, for example, there are various models of microfinance that are more expansive than those in other places. With commercial and customer orientations, the industry has experienced a tremendous increase in demand for related products and services in recent years (Note 5).

Community outreach organizations are best equipped to shepherd oversight of worthy projects and loan repayment. Prior and Argandona (2009) describe microfinancial institutions as intermediaries that extend beyond formal financial services to provide informal assistance in the context of social responsibility. This responsibility includes the need for an oversight of potential moral, ethical, and adverse technical and economic problems. Capital formation for a community can come from a mix of specialized instruments of microfinancial institutions- micro-credit, project financing, asset leasing, loans and advances, and deposit and savings. These financial instruments would not be distributed on the basis of one-size-fits-all. By studying community needs, some mix of the financial instruments could be awarded based on the individual's ability to handle market stress, considering the prevailing circumstances and the systematic market risks. The merits and demerits of each one of the specialized instruments must be articulated to individuals seeking any or some combinations of the instruments. Microfinance projects must ascertain needs of the community and potential entrepreneurs for successful business start-ups. Hermes (2014) and Sherman (1999) studied intervention effectiveness of business start-ups, and each study emphasized the essentials of typical business start-ups.

Having highlighted the prevailing poverty in Dougherty County and the need to alleviate it by establishing microfinance institutions, the researchers of this study have the goal of presenting the specialized microfinance instruments and their understandability and acceptability to alleviate poverty in Albany-Dougherty County, Georgia. 
The organization of the remaining part of this study is as follows: Section 2 provides a comprehensive summary of the dimension of poverty in Albany/Dougherty County, and Section 3 presents the argument for the recipient's accessibility to capital. Characterization of the diverse and specialized microfinancial instruments is the focus in Section 4 , while the characteristics of the target population, research methodology, and results are discussed in section 5. The research conclusion and recommendations for future research are addressed in Section 6.

\section{Summary of Poverty and Its Related Determinants}

Albany/Dougherty County's class stratified (Note 6) and restricted economy highlights a persistent poverty in the Southern United States that has 40\% of the U.S. poor (Riddell et al., 2011, p. 269; Gittleman \& Wolff 2004). Poverty has been persistent in this area since President Lyndon Johnson declared war on poverty about 50 years ago. Natural location as explained in Davis \& Balazs (2011) is one of the exogenous bases for the poverty. The county is also remotely located from the major industrial cities of Atlanta, Georgia, and Tallahassee, Florida, both of which are a few driving hours away. Without personal transportation, it is extremely difficult for individuals to establish contacts for work in the industrial cities; thus, the lack of personal transportation in this remote community restricts geographically from access to jobs, which leads to unemployment and poverty. Since the mid-1970s when Georgia's segment of the Interstate 75 was constructed about 40 miles east of the city of Albany, new economic development has occurred along the highway (Farr \& Slade, 2008). This highway takes business away from the county and increases continuing poverty. East Dougherty County, the most restricted region in the county, has about a 91\% African-American population and a poverty rate of 45\% (Farr \& Slade 2008; Mankiw 2008; Hoynes et al. 2006). Should the restricted region continue to lack entrepreneurship and market norms like microfinancing opportunities (Lui, et al 2006), a vicious cycle of poverty can be the result of persistent race related poverty. Numerous uneducated people in an enlarged poverty class leads to substantial social costs and a comparative disadvantage in a global economy (Bagi 2008).

The dualistic nature of the county that emanated from discrimination and segregation has led to East and West Albany, and this exogenous situation adds to the problem created by the remoteness of the county. The dualist nature does not allow both planning and market conditions to bring about a harmonized economic development. The West and North sides of the county house most of the market institutions and infrastructures, whereas the East and South sides are dotted with small-scale retail businesses and faith-based organizations. Although the poor communities have a higher propensity to consume (MPC) than do the rich communities, there has not been a detailed articulation to harmonize the economic development in the county. If the MPC is considered, an adequate number of businesses that engage in the production and sales of the goods and services that poor people use most may need to be established in the poor communities. The presence of these businesses would enable the impoverished communities to be self-sustaining and the residents of these communities may not have to drive across town to the west and north sides to find employment opportunities.

Limited education of specific and general human capital is a major cause of poverty (Lofstrom and Bates (2007). Education influences one's participation in the labor market, occupational choices, frequency of employment, hours worked, and wage rates and incomes. Quality education is usually cited as the route out of poverty and is positively related to productivity and earnings (Theodos and Bednarzik, 2006, p.43). Beside the positive correlation between these two variables, quality education as an income equalizer is expected to bring about equity in both employment and in earnings. The incidence of poverty is higher for those with limited education. For college graduates, the incidence substantially decreases compared to that of high school dropouts and graduates. D'Amico and Maxwell (1994) observe, for example, the convergence of both the black and white youths' wages when the black youths are able to successfully complete their high school education before beginning work. The county's quality of education, reflected by the graduation rate of $57.44 \%$ and dropout rate of $6.39 \%$, (Note 7) needs improvement. The county's low level of educational achievement results in low-quality human capital that will be offered a non-market discriminatory low compensation and poor work advancement opportunities (Theodos \& Bednarzik 2006, Gardner \& Hern 1992).

Furthermore, Browne (1997) clarifies that the compensation disparity between black and white women is driven by a higher proportion of black women heads of families with low-educational achievements than that of white women. The impact of low-educational achievement, human capital acquisition, and lack of access to financial capital, most especially in the predominantly African-American impoverished community, leads to dominance of business/commercial participations of Asians, White, and Indians in this community. Lofstrom and Bates (2007) posit that while college level education leads to a low level of participation in lower end businesses, lack of a college education and limited net business venture assets tend to inhibit ventures into higher end business opportunities. African Americans tend primarily to exercise leadership in educational, social, and faith-based organizations. These 
are institutions that may be maximizing some values that may not include profits and may not provide enough opportunities for the residents to optimize, if not to maximize, incomes.

In addition, problems posed by crimes (Note 8) lead to life insecurity and economic uncertainty. These adversities affect both planning and location of businesses, most especially in the impoverished communities. Since poverty is associated with higher crime rates, entrepreneurs would hesitate to consider locating their business in impoverished part of the county, (Note 9) such as East Albany. The total adverse effects of substandard education and occupational skills, hedonic consumption, and racial discrimination and segregation in the restricted and dualistic environment account for the extensive and intensive nature of the criminal activities (Note 10). The exodus of both white and middle-class African Americans and of both large and small businesses, particularly from the city of Albany, seem to reflect frustration with increasing city vices and inadequate business sales receipts. As explained in Schmitt 2004, the exit of innovators and major employers from Albany like Firestone, Merck Pharmaceuticals, Winn Dixie and of money resources magnified the involuntary job displacements. In particularly, the exits left some vacant commercial buildings, especially in downtown Albany, and the inner-city poor and working poor are left on their own to experience increased poverty.

As part of the Southern heritage and culture, institutional discrimination and social segregation exist in the county, which exacerbates the aforementioned economic problems. Although a demographic unemployment rate is not available at the county level, a very high unemployment rate among African Americans at the macro level can highlight both institutional discrimination and the reality of the magnitude of the unemployment rate in a restricted environment such as Dougherty County (Blitzer, 2010). A high unemployment rate has been persistent in the description of the county's economy. Also, segregated environments are most likely to lose the benefits of economics of scale, entrepreneurship, and other economic resources. Castillo (1998) points out that the lack of transportation to work can restrict the poor from access to employment opportunities. The residents of the segregated areas such as East Albany, who are highly challenged by lack of transportation to get to West Albany to seek employment, may remain unemployed. With a severe resource scarcity in a segregated area, the struggle to acquire some of the scarce resources could compel some engagements in criminal activities. Since middle income blacks and whites tend to live far from the poor in the segregated areas, the poor and their children stand to lose opportunities to interact with and learn from the economically elite group about work ethic, the importance of education, entrepreneurship, and of other human sustainable norms. The inability to move out of a segregated area can also lead to intergenerational and vicious-cycle poverty and crimes. Therefore, a quality education in particular is expected to increase productivity and to minimize the impact of institutional discrimination that could lead to an underutilization of individual's ability to engage in legitimate economic functions.

Poverty is most likely to show up in an environment where business partnership is not emphasized. Business partnerships are not common among African Americans and may lead to ethnic poverty. Lack of trust among African Americans may also be inhibiting the formation of enduring business partnerships. Instead of forming viable business partnerships, African Americans tend to duplicate partnerships in non-profit and faith-based initiatives. Contrasting the latent business partnerships among African Americans is the pronounced presence of business partnerships among Whites and among the recent immigrants from Asia. These partnerships are apparent even in the predominantly African American neighborhood of East Albany. Many African Americans do not understand the comparative advantage, the economies of size with the associated diminished average cost of operation, and the longevity of small businesses associated with business partnerships. Partnership pulls together the resources-money, diverse talents and specializations - that are desirable for underwriting the initial outlay for establishing small businesses.

For partnerships to survive and to utilize the market related advantages, the partners' interests must be harmonized, and there should be no privately undeclared, divergent or latent interests that could mitigate the overall interest of partnerships. Specifically, partnership can collapse because of some untrustworthiness along with the declared interests in forming a partnership. The ability of a partnership to obtain various microfinance instruments to alleviate poverty depends on trustworthiness and resources of the partnership. For effective use of microfinance instruments in some economic activities, it is imperative for the business partners' mistrust should be substantially minimized. A sufficient business document that articulates all the binding terms and clauses must be voluntarily agreed on by the partners, and there must be a strong desire to sacrifice any personal interest that will mitigate the overall functioning of a business partnership.

Currently, $31.7 \%$ of the Dougherty county's residents fall below the poverty income level, and this rate is substantially higher than the comparable rate of 18.4\% at the state of Georgia level (Note 11). Between 1989 and 2014, while both Georgia State and Dougherty County's annual poverty rates had been increasing, Dougherty County's poverty rates 
were consistently higher than that of Georgia by at least 10 points. Georgia recorded poverty rates of $14.7 \%, 13.0 \%$ and $16.6 \%$ in 1989, 1999 and 2009, respectively, while Dougherty County recorded 24.4\%, 24.8\%, and 28.0\%, respectively, over the same periods (Note 12). These economic adversities in the county seem to prevent the realization of the objective of the Work Opportunity Reconciliation Act of 1996, which highlights employment for resolving poverty. Another factor for understanding the harsh economic reality in the county is an increasing unemployment rate that has risen from $7.4 \%$ in the 1990s to more than $10.2 \%$ by 2009 (Note 13). In the absence of demographic unemployment rate at the county level, the macro unemployment rate from the Great Recessionary economy provides a clue that more people, most especially the minorities, have fallen deep into poverty. In 2008, the rates were $9.2 \%$, $6.4 \%$, and $4.4 \%$ for African Americans, Hispanics, and Whites respectively. By the beginning of 2010, the rates were 17.50\% for African Americans, 12.6\% for Hispanics, and 9.50\% for Whites (Blitzer, 2010).

Since the commencement of the Great Recession, the aggregate incomes of African Americans in particular had decreased by 3\% (Graham, 2009). These estimates highlight the fact that minorities, especially African Americans, experience a depression when White Americans experience a recession. Only a few sectors-education, health care, and defense service in the county-are experiencing marginal growth (Farr \& Slade 2008). In a period of a recessionary mandated hardship, the poor people are most unlikely to have financial institutions of last resorts that can assist them. Just as the Federal Reserve Bank is the lender of last resort to commercial banks, the microfinancing institution may as well be a lender of the last resort to the poor. If microfinancial institutions had been in the county during this recession, they could have addressed the needs of the poor with some kinds of micro financing instruments.

\section{Arguments for Access to Capital}

Possession of entrepreneurial ability may not lead to entrepreneurial activities in the absence of an access to capital. Also, availability of financial resources to small and high risk entrepreneurs is scarce. Banks require an average monthly balance of $\$ 1,000$ for a customer to have access to capital (Note 14). Since obtaining the initial capital to engage any particular business activity is very important, having initial access to capital can provide the avenue to a continuous access to more capital. This situation is particularly possible, for example, when a responsible borrower of a concessionary loan pays the principal and the interest in the term period as provided in the loan covenant. To be successful in any economic activity, before the acquisition of the initial capital, a borrower is expected to have completed the relevant market research on the factors - product or service to be offered, location, customers, cost, price , and the severity of the competition - in the industry in which the borrower expects to conduct a particular economic activity. On the other hand, an inability to produce a relevant market plan for the targeted industry can lead to failure in the market and inhibit future access to capital. Capital as used here is an initial loan and future loans if sought. Future loans can add to the initial capital loan and be used for addressing recurring expenditures. Poor people are likely to have the most difficulty with access to capital.

It is imperative for the poor to have access to capital. Initial capital awarded to any particular poor individual may not be greater than the expected capital expenditure and the related working capital that one expects to incur on a new business. The particular initial capital should be within the limit of the indebtedness the poor could handle. Other events being equal, the initial capital is most likely to be accessed from the financial institutions where any poor individual has been conducting financial transactions within a reasonable period of time. Also, an ability to provide the bank required compensating balance can speed up an access to capital. The compensating balance is the amount in a checking account required from entrepreneurs to provide some level of collateral for capital to be accessed. Without any other considerations, a high compensating balance is most likely to result in a fast access to capital.

The requisite of a compensating balance can inhibit the entrepreneurial ability of the poor. The inability of the poor to provide the compensating balance can be accomplished by setting up microfinancial institutions in which the poor individuals can access capital according to their abilities to acquire debts. Microfinancial institutions that offer concessionary loans are not common in Albany-Dougherty County. These are specialized institutions that address grass-roots poverty. The absence of these innovative institutions could be a substantial factor why East Albany, in particular, has a high unemployment rate of $45 \%$ (Farr \& Slade 2008). Also, the poor's inability to access capital in Dougherty County could emanate from unavailable compensating balances, high cost of capital (interest rate), the presence of racial discrimination, and a lack of adequate market awareness. Compensating balances may not be available since some poor people may not even have the financial accounts in which the compensating balances can be maintained. Some poor may not have had any financial accounts since birth. Additionally, the checks of some poor are likely to be cashed either in check cashing stores or exchanged for the purchase of goods and services.

Poor people are restricted in how their program checks have to be disbursed. Some program checks may not provide the poor with the option to redeem the checks in cash, which can be used for opening bank accounts. Poor people, 
therefore, often redeem their program checks by acquiring goods and services. In this situation, poor people have to have a high financial motivation to be able to find a way out of poverty and start making banking transactions. Without this motivation, the poor can expect a vicious cycle of poverty. In situations where the poor people do not maintain permanent addresses, their purchase transactions are likely to be conducted only in cash, if they are not acquiring goods or services with program checks. Microfinancing institutions with specialized personnel can alleviate these adverse circumstances faced by the poor by providing counseling and by addressing the financial needs of various kinds of the poor. Establishment of microfinancial institutions, especially in the impoverished communities in Albany-Dougherty County, can foster financial market competition that will benefit the poor citizens.

Adverse conditions of contemporary racial discrimination and segregation can impact accessibility to innovative capital. Discrimination as interpreted here is from Gary Becker in Borjas (2008). Minority members are discriminated against in the labor market by denial of employment or by underemployment. As in the labor market, discrimination in the financial market can be accomplished by denying lending to minorities and by requiring minority borrowers to observe very high levels of collaterals or compensating balances. Specialized micro lending will serve to mitigate both financial comparative disadvantage and high cost of capital that the poor and some members of the minority groups may face in the financial market.

Discrimination will become more pronounced as capital, like any other economic factor, becomes scarcer while demand for capital remains unchanged or increases. If the poor have to compete for capital with the rich, there may never be an end to poverty. Specialized financial sectors like microfinancial institutions can provide the competitive shield for the poor to have access to capital. When scarcity of capital becomes pronounced, access of the poor to specialized funds can be addressed by policy provisions that guarantee funds availability to the poor, as a means to empower the poor economically. When ideological and philosophical citations are introduced in the discussions of advancing the economic opportunities of any racial group, African American in particular, the advancement opportunities may be interpreted as race-based economic empowerments detrimental to other racial groups. A strong opposition to empowering the poor and minority in particular contends that the financial market, like any other market, should not show any kind of benevolence toward any particular group. Such opposition may want the unregulated price of capital, not planning and mandates, to decide the outcome of a financial market. Arguments such as these, however, do not allow economic access for the poor in an economically industrialized economy.

However, assisting the poor financially may lead to an expanding economy in which every citizen has some opportunity to add some value. Daru et al (2005) articulate the importance of microfinance products and services to assist the poor in eliminating indebtedness in some developing countries. Albany-Dougherty County's contemporary economy harbors an ethnic-related poverty (especially among African Americans) that could be compared to that in the developing countries. Albany-Dougherty County can, therefore, require microfinancial institutions which will complement the traditional financial market to provide the specialized funds that will financially uplift the poor and African Americans in particular. Encouraging the participation of the poor and African Americans in the market economy is one of the ways to diminish poverty without high investments or payments of eradicating or reducing poverty.

People's lifestyles do impact their accessibility to innovative capital. Given the high marginal propensity to consume (MPC) associated with the poor, the poor cannot naturally save enough to provide the compensating balances required for access to capital. Some poor may choose to participate in American free enterprise activities and to save if they are educated, counseled, encouraged, and motivated by the rewards of the economic markets. Microfinancial institutions with specialized personnel can accommodate this special group of citizens in developing their market skills. Specific financial institutions such as microfinancing establishments have enabled the promotion of both the poor's financial understanding and the diminishing of poverty in an impoverished economy (Morduch 2002, Khandker 2005). The benefits of microfinancing have been realized in some impoverished environments with expanded market awareness among the poor and reduced poverty (Morduch, 2002; Khandker, 2005).

\section{Micro Financial Instruments in Albany-Dougherty County, Georgia}

This section provides the description of each of the microfinancing instruments as applicable to Albany- Dougherty County, Georgia. The focus here is to highlight the general attributes, merits and demerits of each instrument. Consideration of the instruments can determine how much the poor is assisted with a particular instrument or with some combination of the instruments.

Microfinance incubator projects and other like incentives have demonstrated ongoing positive success. The 1987 Lakota Fund and Pine Ridge NAIR in South Dakota are known to have increased participants' per capita incomes from 1987 to 2006 (Benson, 2011). Dougherty County does not have specialized financial institutions established purposely 
for increasing the poor's financial understanding to diminish poverty. Specialized establishments seem to address the importance of small exogenous investments that are sufficient to bring about decreased poverty. This achievement was realized by using the appropriate financial instruments to encourage the participation of the poor in economic development processes with its accompanying developmental jolt in the impoverished economies that would lead to a new way of financial thinking. Hence, the application of various financial instruments to address the plight of the poor in Albany-Dougherty County should generate the same jolt and the expected consequences in an impoverished community.

The implementation of these specialized financial institutions will allow for policy flexibility without the prohibitive compensating balances and collaterals that are often required to establish the credit worthiness of the poor by the conventional financial intermediaries. Using appropriate instruments, providing concessionary loans and advances, other financial assistances, and economic awareness, the microfinancial institutions can address the economic plight of a particularly poor community. Increased financial awareness of the poor will enable their understanding of resource scarcity and, therefore, of their obligatory payment of the opportunity cost of capital (interest rate) of any financial advancement received. As the citizens become increasingly aware of the functions of the financial markets, their economic thoughts will reflect the functions of a contemporary economy. Understanding the fundamentals of a market-oriented economy could in the long run diminish the adversities posed by poverty, unemployment, and crimes in Albany-Dougherty County.

Some microfinancial instruments that can be applied in the Albany-Dougherty County are as follows:

(a) Micro Credit: This credit financing instrument can support small scale budgets for the very poor who exhibit the potential to succeed in commercial activities. The poor who need this assistance may not have financial accounts of any nature. Ahmed et al (2001) found an insignificant impact of micro credit on the poor who were the recipients of the micro credit in Bangladesh. Traditional or cultural norms could be responsible for the lack of the expected significant impact of the micro credit. Financial education, therefore, is important to encourage the poor's evolutionary process into the financial market and a shift from hedonic activities. Selecting people for micro credit may be based on their interview responses that signal their propensity to succeed. Those to be assisted may have been in the economic market before they encountered some market difficulties that removed them from the market without rewards. Hence, this small credit can be designed to jumpstart the first-time market participants and those that have participated but failed in some past market ventures. This concessionary credit can be applied to the acquisition of working capital or inventory and market demanding skills or vocations. Also, this kind of credit can be applied to purchasing transportation for work, especially after the acquisition of the economy's demanding skills or vocations.

(b) Project Financing: Microfinancing can activate the entrepreneurial ability of the poor and could especially elevate the increasing growth of businesses owned by young and educated African Americans (Bates 1997, 2006). According to the credit worthiness of poor individuals, credit can be advanced into the poor person's account, and a delinquent account can be bubbled up with some level of credit. With project financing instruments, the poor can be asked to identify a commercial project of interest to produce or sell some goods or service. This project can be home equipment, or retail space, with which the poor could engage in some small-scale entrepreneurial activity. The credit can be used to acquire some kind of goods for sale at the flea market or at a garage sale. In this era of global internet business, project-advanced credit can also be used to acquire computer and internet access to engage in a small-scale selling. Homemade goods can be marketed through this channel. With this mode of selling, the poor will learn the art and science of e-commerce.

Short-term credit may be scheduled for three to six months after which evaluation of the credit can be conducted. Within the period, if the poor is able to maintain the respective account by at least being able to pay the minimum payment required, the credit and the term period could be extended. The potential of the poor and the project need to be frequently assessed to prevent either undercapitalization or overcapitalization. After credit is awarded to a particular account, the account should be monitored periodically to understand the entrepreneurial activities of the poor. Most importantly, monitoring the account ensures certainty that the project is aligned with the purpose for which the credit was advanced.

(c) Asset Leasing: This financing opportunity is one of the ways of providing access to capital for the would-be-market innovators who are not able to secure equipment loans from the conventional sources. Asset leasing — acquiring assets by paying the periodic rent on the assets — is very important when the cost of buying productive equipment is too large to be initially underwritten by the poor. To be assisted by this financing method, therefore, the poor can use the microfinancing institutions to lease the assets instead of buying them. 
Asset leasing becomes even more important when there is no trustworthiness for establishing some kind of business partnership to raise the initial capital required for purchasing the relevant equipment or assets. This financial assistance can allow the poor to receive the minimum monthly amount required to cover the rent on the assets leased from the microfinance institutions. The poor can also be required to provide financial self-support for the payment on the space to house the leased equipment and other related costs and expenses.

(d) Loans and Advances: Making concessionary soft loans or providing some kind of advances to select groups of the poor (farmers, for example) provides another opportunity for the poor to acquire specialized funds and understand the cost of capital and the associated term period. Soft loans are very small cash amounts that can be paid directly to the poor, and advances are usually deposits paid into the qualified poor customer's account for withdrawal. Microfinancial institutions could withhold the applicable interest on the soft loans or advances to limit customer access. Alternatively, the poor can be required to pay the applicable interest within a specific period after the customer has taken the loan or received the advances. Missing interest payments could raise a red flag or signal that the poor may not understand the full ramifications of credit. Insisting on interest payment can enable the poor to understand that the saver-depositors are expecting payment from the borrower-spenders for the use of the savers' funds. Paying interest on funds when it is due, as in conventional financial institutions, would be helpful to the poor to develop financial responsibility and market discipline. The poor consumer who pays the interest and the principal when due could have his or her credit lines increased. With time in the financial market, the participating poor would start to engage in economic analyses involving opportunity cost, marginal concept, specialization, trade, and consumer rationality.

(e) Deposit and Savings: Some poor people may not have made financial transactions in the past or, as in rural Albany-Dougherty County, some may have discontinued their financial transactions because of poverty. It needs to be mentioned here that only about $10 \%$ of African Americans own stocks and bonds in the U.S. (Lui, et al 2006, p. 77). In Albany-Dougherty County, with highly limited financial institutions and infrastructures, one would expect that a very small number of poor people will learn how the financial markets work. Deposit and savings opportunity provides another avenue for the poor to participate in the financial transactions. The assistance from this opportunity could encourage the poor to open up savings accounts with initial small deposits provided by the microfinancial institutions. The poor will be responsible for refunding the deposits at concessional terms in some particular time period and can be asked to make a small deposit on the assisted account at some specific periods of time. Understanding that savings accounts attract interest payment will enable the poor to understand that interest must be paid for borrowing the savers' deposited funds. The overall effects from the mix of the financial instruments can create financial awareness and increase the level of participation of the poor in economic markets. The poor's increased earnings and participation in the markets would, therefore, diminish poverty and other misery indexes. Economic markets, not program incomes, entitlements, and handouts, will therefore maximize the earnings of the poor over time.

\section{Characteristics of the Target Population, Research Methodology and Results}

Most often, politicians, bureaucrats, and pastors, who may not have experienced poverty, are the advocates for reducing poverty. Temporary or term measures, in most cases, are advocated for alleviating poverty, and a real market activity can reduce poverty in the long run. This study identifies the poor as a group of human casualties of our contemporary competitive free economy that mostly emphasizes profit maximization. Therefore, this study proposes that a group of human beings that experiences poverty regularly should have access to financial opportunities for self-development in our voluntary market economy. In Albany-Dougherty County, there are no concessionary banks or strong financial programs that challenge the poor to participate in the economic markets.

Some of the poor may have resigned themselves to their situations, while others may still be holding tight to their American dreams, despite being economically marginalized by circumstances beyond their control. They may have experienced poverty because of the loss of jobs, life disturbances in families, or some economic impediments that prevent them from participating in the marketplace to maximize profit, as other market participants. Some of the poor who are still determined to succeed in the economic markets have yet to see entrepreneurs and financial institutions like microfinance establishments which would encourage their participation in economic markets. This exploratory study, therefore, establishes the feasibility of the poor using some kinds of microfinance instruments for participation in the economic markets.

This study calls for the establishment of microfinancing institutions as critical enablers to alleviate poverty among the poor and improve access of the poor to economic markets. These critical interventions can lead to an upward mobility of the poor in the market economic ladder. Based on the research objective of encouraging the poor to participate in the 
economic markets with the establishment of microfinancial institutions, many of the poor, including those experiencing abject and vicious cycle of poverty, are capable of engaging in some kind of market activities to alleviate their poverty.

\section{Theoretical Models for the Poor's Expected Incentive from the Market}

A poor individual is expected to exercise some effort in the implementation of a particular instrument or some instruments to engage in some economic activities. An individual's income from the market can be a function of the presence of the microfinancing instrument (mf) and of self- related market attributes (ma) of the poor. This general function can be stated as:

$$
\text { income }_{\mathrm{t}}=f(\text { (mf, ma). }
$$

Income is driven by the direct impact of the exogenous factors in the equation (1). Positive relationships are expected between income and each of the deterministic factors. For example, the activities of the micro finance instruments can be awarded to the particular poor, and the poor will understand that there are risks associated with the use of any of the instruments in the economic market.

Another theoretical model that could explain an income improvement of the poor participating in the market is the market risk premium-income model. This model incorporates some market risks that the poor have to understand when using the micro instruments in a competitive market. Instead of the poor depending on a program income, this model explains how much premium there is from using a particular microfinancial instrument in the market to create income that is over or beyond the program income. The premium is the difference between the expected incomes from all sources or expected market income from a particular microfinancial instrument and the risk-free dependent (program) income. The market income model is explained in the following equation (2):

$$
\text { Market Risk premium }=\mathrm{RET}^{\mathrm{e}}-\mathrm{RET}_{\mathrm{f}}=\beta\left(\mathrm{RET}_{\mathrm{m}}^{\mathrm{e}}-\mathrm{RET}_{\mathrm{f}}\right) \text {, }
$$

where

$\mathrm{RET}^{\mathrm{e}}=$ expected income from all sources but market. This income underscores that the poor could attract some additional income on top of the dependent (program) income.

$\mathrm{RET}_{\mathrm{f}}=$ Risk-free dependent or program income

$\beta=$ Beta of the market and $\beta>1$

$\mathrm{RET}_{\mathrm{m}}^{\mathrm{e}}=$ Expected income from the market income.

The poor may be willing to engage a particular market instrument with some systematic risk (Note 15) only if the instrument is deemed to have a market income that reflects the magnitude of the market risk given by beta.

Multiple Market-Instrument Incomes Theoretical Model: This model assumes that there is more than one source (factor) of systematic risk that can be found in the mix of the market instruments. Here, instead of considering just one beta as in the first equation, more betas are considered as in the following equation (3):

$$
\begin{aligned}
& \text { Market Risk premium }=\mathrm{RET}^{\mathrm{e}}-\mathrm{RET}_{\mathrm{f}}=\mathrm{B}_{1}\left(\mathrm{RET}_{\text {factor 1 }}^{\mathrm{e}}-\mathrm{RET}_{\mathrm{f}}\right)+\mathrm{B}_{2}\left(\mathrm{RET}_{\text {factor } 2}^{\mathrm{e}}-\mathrm{RET}_{\mathrm{f}}\right)+ \\
& + \text {. ..... }+\mathrm{B}_{\mathrm{K}}\left(\mathrm{RET} \text { factor } \mathrm{K}-\mathrm{RET}_{\mathrm{f}}\right) \text {. }
\end{aligned}
$$

The risk premium for a particular instrument and the associated risk are related. As the poor increasingly embrace market attributes and understand the associated market risks, microfinance institutions can award multiple instruments to the deserving and enterprising poor to engage in various legitimate activities in the market. The poor could eventually become rich.

\section{Summary from Assessment from Survey Data}

A sample size of 209 people responded to a survey instrument on community awareness of concessionary lending from microfinance institutions on entrepreneurship and on financial education. The evaluative outcome from the responses will provide the basis to advocate for the establishment of microfinance institutions to financially support the community and reduce poverty. Only recipients whose annual per capita incomes are below the official poverty income levels completed the survey instrument. The survey response included any poor regardless of gender and ethnicity. The descriptive statistics of the responses will be used to characterize the poor's desire to self-elect particular microfinance instruments to engage in market activities. The discussion on the descriptive statistics will include the use of microfinancing instruments to diminish poverty. Only individuals whose family annual incomes from all sources that are below the poverty income levels (Note 16) responded to the survey instrument. The following Table 1 provides 
some critical type A and B estimates. These estimates provide different platforms for characterizing the market traits and the entrepreneurship of the economically challenged.

Table 1. Estimates of the measured traits

\begin{tabular}{lll}
\hline Traits & Type A Estimates & Type B Estimates \\
\hline Concessionary Loans & of awareness: 8\% & of unawareness: 92\% \\
$\begin{array}{l}\text { Motivation for } \\
\text { Accepting Loans }\end{array}$ & of willingness: 52\% & of unwillingness: 27\% \\
$\begin{array}{l}\text { What Could be Done } \\
\text { With Small Loans }\end{array}$ & $\begin{array}{l}\text { of debt payments and } \\
\text { consumption: } 61 \%\end{array}$ & of entrepreneurship: $17 \%$ \\
$\begin{array}{l}\text { Possession of Bank } \\
\text { Accounts }\end{array}$ & of ownership: 53\% & of non-ownership: $47 \%$ \\
Educational & & \\
Attainment & of college: $46 \%$ & of high school or less: \\
& & $54 \%$ \\
N=209 & &
\end{tabular}

Generally, the performance of the poor on the assessment survey regarding the desire to participate in the economic market is unacceptable. Some of the poor tended to be more concerned about consumption than about production. This is not surprising given the poor's long orientation of not engaging in production and sales. Some may not have participated even in some petty sales. On the question of awareness about financial institutions that could provide concessionary loans to the poor, 92\% ( $\mathrm{n}=209)$ of the responses expressed lack of awareness of any financial institutions that could loan money to the poor. Only $8 \%$ of the responses on the same question indicated an awareness of financial institutions that could loan to the poor. The high percentage of the responses indicating unawareness of financial institutions providing concessionary loans to the poor indicates that the poor is largely excluded from the financial market and, therefore, from the free enterprise economy. As in the economies that have had the economic spread effect of microfinance institutions, the economy of Albany-Dougherty County could benefit from the developmental boost of microfinancing establishments.

The survey also indicated that some disadvantaged citizens may not accept loans if available. Only $52 \%$ of the respondents indicated that they would be willing to obtain concessionary loans if made available. Hence, a large proportion of the poor in Albany-Dougherty County may not be willing to take advantage of concessionary loans perhaps due to mistrust of the establishments and/or lack of education. The negative responses to obtaining loans were $27 \%$ on the same question and may highlight recipients who do not want to participate in the product market but want to acquire some market related skills for work to earn income for enhancing consumption. Twenty-one percent of the responses on the same question expressed the desire to think about receiving concessionary loans. These responses also included some recipients who would need financial education or the acquisition of contemporary skills to move beyond poverty. Microfinancial institutions could be an integral part of educating and encouraging the poor to use these productive tools.

Responses to the question about what can be done with a small or soft loan are skewed toward paying past debts and purchasing clothes and groceries. Paying past debts responses account for $61 \%$ of the entire responses to the question, a percentage that highlight that disadvantaged recipients are mostly interested in earning incomes for various bills in a contemporary America. On the same question, 22\% of the responses expressed the intention to use loaned money to purchase clothes and groceries. With this ratio, some poor may need financial training, which is one of the functions of the specialized services of the microfinancial services. Only seventeen $17 \%$ of the responses show some kind of 
entrepreneurial trait highlighting the desire to use loaned money for purchasing goods for resale. The recipients who indicated these responses can most likely acquire the financial skills and engage in entrepreneurial activities. With these traits, a recipient in this category can be the immediate candidates for training in the specialized services of the microfinancial institutions with the goal of alleviating poverty.

Introducing a potential recipient to some specialized accounts of microfinancial institutions is another tool for alleviating poverty. With everything else being equal, this introduction will enable a recipient to understand the importance of money as it relates to the future value of today's dollars. Potential recipients' consumption choices could also change with higher income levels. Those who are able to improve their market skills could start to participate in the financial market at the level where decisions rest on due considerations for opportunity cost and marginal analysis procedures.

On the question of disadvantaged consumers' ownership of some kinds of bank accounts, the responses are almost equally distributed between possession and non-possession of bank accounts. Respectively, 53\% and $47 \%$ of the responses expressed ownership and non-ownership of bank accounts. Non-ownership of bank accounts means that most poor settled transaction exchanges in cash or in kind and must have been redeeming their program checks in cash and paying some fees for doing so instead of depositing the checks in some interest-yielding accounts. Having some reasonable compensating balances in bank accounts could qualify microfinance applicants for some concessionary loans to engage in market-related businesses.

With the presence of microfinance institutions, most of the poor can be asked to open up some kind of accounts related to incomes and expenditures. These interest-yielding accounts could lead the poor to understand the apparent reason why future consumption may be preferred over today's consumption. Just like having a passport ready for future travelling, having some specialized accounts could likely enable the poor to appreciate the return on money in saving accounts. Appreciating the returns on saved money can also enable the poor to appreciate the sources of their program income checks and realize that some citizens have decreased consumption by paying taxes that may contribute to the program checks.

As with the distribution of the responses on the question of possession of bank accounts, the educational attainment responses show that the poor are again roughly equally distributed between having a high school and a college education (two-year or four-year college). Respectively, $47 \%$ and $46 \%$ of the responses on educational attainment present the poor as having high school and college education. Only $7 \%$ of the responses on the same question classified the poor as having grade school education. A distribution such as this signals very low-specific and general-human capital and low levels of contemporary skills and experience. As presented by Joseph Schumpeter in the nineteenth century, specific human capital, and general human capital are essential for promoting entrepreneurship and economic development. Dougherty County's limited market environment can benefit from unique financial institutions such as microfinancial institutions which provide financial literacy, concessionary loans, and specialized services.

The following graph shows the frequency of the responses that matched the official household income for a household which is declared poor. The chart shows that most family income responses are roughly distributed between $\$ 10,890.00$ and $\$ 14,710.00$, incomes established for family households of one and two members respectively.

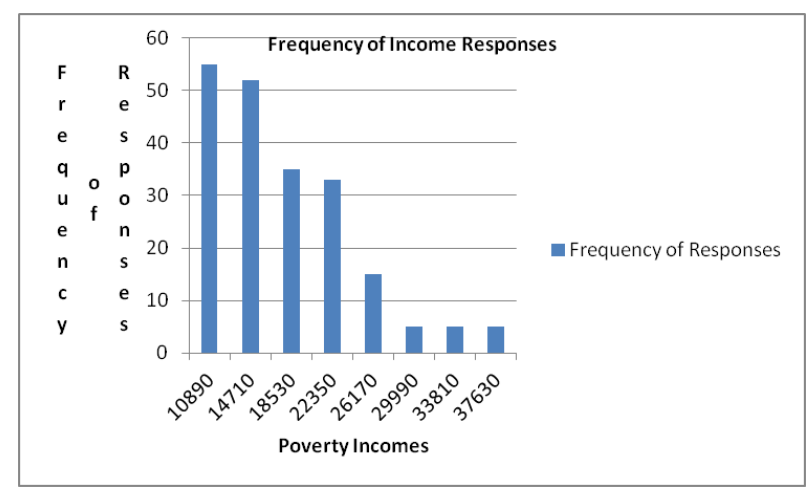

With this income of $\$ 14,710$ (official poverty income level for a two-member household), the annual per capita income of the household is $\$ 7,355.00$. The next concentration of the responses is on the income levels of $\$ 18,530.00$ and $\$ 22,350.00$, officially established for three-person and four-person households. The per capita incomes for these 
households are $\$ 6,177.00$ and $\$ 5,588.00$ respectively. There were few responses on the income level of $\$ 26,170.00$ officially established for five-member households, and the responses become fewer on the income levels of $\$ 29,990$, $\$ 33,810$ and $37,630.00$, officially established for six- and seven- and eight-member households. Per capita income tends to decline as the number of household members increases. With a limited education and the respective per capita incomes, it is clear that some of the poor in the county are not prepared for the labor market where the exhibited effort commands wage compensations that reflect the physical marginal product of labor. Inadequate formal education and limited vocational training may tend to inhibit the poor's understanding of the functionality of contemporary economic markets where most incomes are realized.

\section{Conclusion and Suggestions for Future Study}

This study has explored the poverty level in Albany-Dougherty County and the need to use the micro finance sector to alleviate poverty by providing financial literacy, specialized services, and concessionary lending. Consumption-oriented rather than production-oriented, the poor in the county do not understand or participate in the American free-enterprise economy. They have been excluded from the economic markets where incomes potentials tend to be higher than dependent incomes. A vicious circle of poverty is the outcome when a large number of the county's residents does not understand or engage in market activities, and poverty-related indexes highlight a vast poverty in the restricted, stratified and dualistic county. A substantial poverty rate greater than the comparable rate at the state of Georgia level indicates that a larger percentage of the county's residents fall below the poverty income level.

Also, a very high and persistent unemployment rate characterizes the harsh economic reality in the county. With a very high unemployment rate, African Americans, who constitute the majority in the county, tend to endure a continuous depression, not a recession. With a recessionary mandated hardship, the poor citizens are unlikely to have any access to conventional financial institutions as last resorts to financially address their plights.

There is no presence of microfinancing institutions to address the needs of the poor using microfinancing instruments. Thus, poverty could be diminished in the county with the introduction of microfinancial institutions that provide concessionary lending and other financial services. The microfinance sector has proved to be innovative in alleviating poverty in some impoverished communities because of its ability to accommodate financial inclusion (diversity) and support for specialized financial lending and services. These traits become very important since the conventional banks may not have the goal of serving some underserved communities. Given racial discrimination and segregation, a high unemployment rate, a high marginal propensity of the poor to consume, the need for microfinancing sector to assist the poor financially cannot be overemphasized. Also, the conventional bank requirement of compensating balances for customers to access capital would necessitate the establishment of a microfinancing sector to provide concessionary loans and services, and to offer a liberal policy on compensating balances. Additionally, establishment of the microfinancing sector would reduce check cashing fees and other applicable charges paid by the poor when redeeming their program checks in cash.

Diversity in microfinancing instruments - micro credit, loans and advances, project financing, deposit and savings, and asset leasing - is elaborated. Each instrument's attributes, merits and demerits are evaluated as ways to assist the poor. A risk premium-income model is theoretically introduced to explain an income improvement of the poor participating in the market, and basically, the model encourages the poor to use a particular instrument to earn the most income that is over and above a program or entitlement income.

Poor people do not seem to understand the benefits of participating in the economic market; they tend to rely on given opportunities instead of finding small ways to create some opportunities. Additionally, poor people might not have a strong desire to seek cheap loans and may not even accept concessionary loans because they lack the necessary means and education and trust in the established financial institutions. Those who accept loans would rather apply the loans to paying past debts and purchasing clothes and groceries. Most poor people do not possess bank accounts and, therefore, would prefer to redeem their checks in cash with high fees and settle transactions in cash or in kind. Without bank accounts, compensating balances cannot be created for soft loans.

Among the poor citizens of Albany-Dougherty County, there is a balanced distribution between poor people who have either a high school or college education. Most household incomes align with the officially established poverty income levels for households of one and two family members. Per capita income of households declines as the number of household members increases. Given the low levels of educational achievements and income per capita, it is apparent that most poor citizens of Albany-Dougherty County do not have adequate financial preparation for the labor market or take advantage of market incentives and other opportunities.

As in other impoverished communities that have benefitted from the microfinancial sector, Albany-Dougherty County needs the intervention of this sector. This sector can provide the necessary and sufficient financial awareness and 
literacy, specialized credit assistances, and concessionary loans and advances from the diversified microfinancial instruments. Also, it could reduce the resistance of the poor to accepting loans, and preference for using loans and advances to pay debts and purchase clothes and groceries. The microfinance sector can provide a financial boost in the county and improve the poor's desire to benefit from market and economic incentives. Market rewards will then be preferred over the program incomes. Future study on this topic should focus on the market risk beta by which the return from market is adjusted and how microfinance instruments can complement education and training as strategies for alleviating poverty.

\section{References}

Ahmed, Syed M., Mushtaque Chowdhury, \& Abbas Bhuiya. (2001). Micro-Credit and Emotional Well-Being: Experience of Poor Rural Women from Matlab, Bangladesh. World Development, 29(11), 1957-1966. https://doi.org/10.1016/S0305-750X(01)00069-9

Bagi, Sukhwinder. (2008). An Analysis of Inequality, Human Development, and Economic Growth. Southwestern Journal of Economics, $x(2), 69-80$.

Benson, David, Aaron Lies, Albert Okunade, \& Phanindra Wunnava. (2011). Economic Impact of a Private Sector Micro-financing Scheme in South Dakota. Small Business Economics, 36(2), 157-168. https://doi.org/10.1007/s11187-009-9191-9

Blitzer, Wolf. (2010, February 10). The Situation Room. CNN Live.

Borjas, George. (2008). Labor Economics (4 ed.). McGraw-Hill/Irwin, New York.

Browne, Irene. (1997). Explaining the Black-White Gap in Labor Force Participation among Women Heading Households. American Sociological Review, 236-252. https://doi.org/10.2307/2657302

Castillo, Monica D. (1998). Persons outside the Labor Force Who Want a Job. Monthly Labor Review, 34-42.

D'Amico, Ronald, \& Nan L. Maxwell. (1994). The Impact of Post-School Joblessness on Male Black Wage Differentials. Industrial Relations, 184-205. https://doi.org/10.1111/j.1468-232X.1994.tb00335.x

Daru, Patrick, Craig Churchill, \& Erick Beemsterboer. (2005). The Prevention of Debt Bondage with Microfinance-led Services. The European Journal of Development Research, 17(1), 132-154. https://doi.org/10.1080/09578810500066704

Dougherty County School System. (2002-2009). DCSS Graduation \& Dropout Rates. Dougherty County School System. Albany, Georgia.

Farr, Jessica L., \& Sibyl S. Slade. (2008). Albany, Georgia: the East Albany Neighborhood. Albany Georgia.

Garder, Jennifer M., \& Diane E. Hern. (1992). Working and Poor in 1990. Monthly Labor Review, 20-28.

Gittleman, Maury, \& Edward N. Wolff. (2004). Racial Differences in Patterns of Wealth Accumulation. The Journal of Human Resources, 39(1), 193-227. https://doi.org/10.2307/3559010

Graham, Leigh. (2009, September 14). White Recession, Black Depression. Change.org, 1-3.

Hermes, H. (2014). Does Microfinance Affect Income Inequality?. Applied Economics, 46(9), 1021. https://doi.org/10.1080/00036846.2013.864039

Hoynes, Hilary W., Marianne E. Page, \& Ann Huff Stevens. (2006). Poverty in America: Trends and Explanations. Journal of Economic Perspectives, 47-68. https://doi.org/10.1257/089533006776526102

Khandker, Shahidur R. (2005). Microfinance and Poverty: Evidence Using Panel Data from Bangladesh. The World Bank Economic Review Advance Access, 1-24. https://doi.org/10.1093/wber/lhi008

Lofstrom, Magnus. (2007). African Americans' Pursuit of Self-Employment. Institute for the Study of Labor. Discussion Paper No. 3156.

Lui, Meizhu, Barbara Robles, Betsy Leondar-Wright, Rose Brewer, and Rebecca Adamson and United for a Fair Economy. (2006). The Color of Wealth. The New York Press. New York.

Mankiw, N. Gregory. (2008). Principles of Microeconomics (5 ${ }^{\text {th }}$ ed.). South-Western Cengage Learning, USA.

Morduch, Jonathan. (2002). Analysis of the Effects of Microfinance on Poverty Reduction. NYU Wagner Working Paper. Robert F. Wagner Graduate School of Public Service, New York University, 1-163.

Nwaokoro, Amaechi. (2012). Sources, Stigmatization, and Alleviation of Poverty in Albany/Dougherty, Georgia. The Journal of Applied Business Research, 28(2), 155-170. https://doi.org/10.19030/jabr.v28i2.6839 
Prior, Francesc, \& Antonio Argandona. (2009). Credit Accessibility and Corporate Social Responsibility in Financial Institutions: the Case of Microfinance. Business Ethics: A European Review, 18(4), 349-363. https://doi.org/10.1111/j.1467-8608.2009.01568.x

Riddell, Tom, Jean A. Shackelford, Stephen C. Stamos, \& Geoffrey Schneider. (2011). Economics: A tool for Critical Understanding Society: Pearson: Prentice Hall. Upper Saddle River. NJ.

Schmitt, John. (2004). The Rise in Job Displacement, 1991-2004. Challenge, 46-68.

Servon, Lisa, \& Timothy Bates. (1998). Microenterprise as an Exit Route from Poverty: Recommendations for Program and Policy Makers. Center for Economic Studies, Washington Plaza II, Room 211, Bureau of the Census, Washington, DC. https://doi.org/10.1111/j.1467-9906.1998.tb00430.x

Sherman, Hugh. (1999). Assessing the Intervention Effectiveness of Business Incubation Programs on New Business Start-ups. Journal of Developmental Entrepreneurship, 4(2), 117-133.

Theodos, Brett, \& Robert Bednarzik. (2006). Earnings Mobility and Low-wage Workers in the United States. Monthly Labor Review, 34-47.

U.S. Bureau of the Census. (2000). Income and Poverty in Dougherty County. U.S. Bureau of the Census.

\section{Notes}

Note 1. The estimates are retrieved from: http://www.city-data.com/county/Dougherty_County-GA.html;

Note 2. The estimates are retrieved from: http://www.city-data.com/county/Dougherty_County-GA.html.

Note 3. The estimate is retrieved from:http://doughertycounty.georgia.gov/03/home/0,2230,8466851,00.htm1

Note 4 .

https://www.google.com/search?q=Microfinance\&client=firefox-a\&hs=obP\&rls=org.mozilla:en-US:official\&tbm=is ch\&tbo=u\&source $=$ univ\&sa=X\&ei=XRhoUv-nF4Kr2wX8-oA4\&ved=0CH8QsAQ\&biw=1920\&bih=934

Note 5. See: (Morduch 2002, Khandker 2005) and “An Inside View of Latin American Microfinance” by Marquerite Berger

Note 6. Agriculture does not yield substantial income. At the Federal level, roughly $52 \%$ of farmers earn more than $\$ 8.00$ per hour (Theodos and Bednarzik 2006, p.36).

Note 7. Dougherty County School System provided these estimates.

Note 8. The crimes indexes are accessible at: http://services.georgia.gov/gbi/crimestats/viewCrimeStatReport.do

From 2000 and 2010, the various crimes in the county included vehicle theft, larceny, burglary, assault, robbery, rape, and murder. Crimes increased by $17 \%$ in the period of XXXX and the number of people admitted to jail exceeded the number of the released from jails.

Note 9. http://www.dcor.state.ga.us/GDC/OffenderStatistics/jsp/OffStatsResults.jsp

Note 10. See http:services.georgia.gov/gbi/crimestats/viewCrimesReport.do

Note 11. 2014 Poverty Rate Estimates by the USDA, Economic Research Service

Note 12. Poverty Rate Estimates by the USDA, Economic Research Service

Note 13. Source: Georgia Department of Labor

Note 14. www.capitolcitybank-atl.com

Note 15. Systematic risk is measured by beta-measures the behavior (sensitivity) of an instrument's return to the changes in the market portfolio of instrument as

$$
\beta=\frac{\% \Delta \text { in instrument's value }}{\% \Delta \text { in market portfolio of instrument }}
$$

If the change in asset's value is less than the change in the market portfolio of instruments, the systematic risk is low. Any asset with a high beta is associated with high systematic risk, and is less desirable in the portfolio of assets and therefore should have a high market risk premium.

Note 16. See 2011 Poverty Guidelines at: http://aspe.hhs.gov/poverty/11 poverty.shtm1 